\title{
Human adult bone marrow-derived stem cells decrease severity of lipopolysaccharide-induced acute respiratory distress syndrome in sheep
}

Mauricio Rojas ${ }^{1,2,3,4^{*}+}$, Nayra Cárdenes ${ }^{1,3+}$, Ergin Kocyildirim ${ }^{4,5}$, John R Tedrow ${ }^{1,3}$, Eder Cáceres ${ }^{3}$, Robert Deans ${ }^{6}$, Anthony Ting ${ }^{6}$ and Christian Bermúdez ${ }^{4,5}$

\begin{abstract}
Introduction: Acute respiratory distress syndrome (ARDS) is the most common cause of respiratory failure among critically ill subjects, sepsis and severe bacterial pneumonia being its most common causes. The only interventions that have proven beneficial are protective ventilation strategies and fluid conservation approaches. New therapies are needed to address this common clinical problem. Others and we have previously shown the beneficial effect of infusion of exogenous adult stem cells in different pre-clinical models of ARDS.

Methods: In the present study endotoxin was infused intravenously into 14 sheep from which 6 received different doses of adult stem cells by intrabronchial delivery to evaluate the effect of stem cell therapy.

Results: After administration of endotoxin, there was a rapid decline in oxygenation to hypoxemic values, indicative of severe-to-moderate ARDS. None of the animals treated with saline solution recovered to normal baseline values during the 6 hours that the animals were followed. In contrast, sheep treated with a dose of 40 million adult stem cells returned their levels of oxygen in their blood to baseline two hours after the cells were infused. Similarly, improvements in carbon dioxide $\left(\mathrm{CO}_{2}\right)$ clearance, pulmonary vascular pressures and inflammation were observed and confirmed by histology and by the decrease in lung edema.

Conclusions: We concluded that instillation of adult non-hematopoietic stem cells can diminish the impact of endotoxin and accelerate recovery of oxygenation, $\mathrm{CO}_{2}$ removal and inflammation in the ovine model, making the use of adult stem cells a real alternative for future therapies for ARDS.
\end{abstract}

\section{Introduction}

Acute respiratory distress syndrome (ARDS) is a common clinical entity and a major cause of morbidity and mortality in the critical care setting [1]. The recent Berlin definition classifies it in three different degrees of severity according to the level of hypoxemia, calculated as: mild, 300 to $201 \mathrm{mmHg}$ partial pressure of oxygen $\left(\mathrm{PaO}_{2}\right) /$ fraction of inspired oxygen $\left(\mathrm{FiO}_{2}\right)$; moderate, 200 to $101 \mathrm{mmHg} \mathrm{PaO}_{2} / \mathrm{FIO}_{2}$; and severe, $\mathrm{PaO}_{2} / \mathrm{FIO}_{2} \leq$ $100 \mathrm{mmHg}[2,3]$.

\footnotetext{
* Correspondence: rojasm@upmc.edu

${ }^{\dagger}$ Equal contributors

'Dorothy P. and Richard P. Simmons Center for Interstitial Lung Diseases, University of Pittsburgh School of Medicine, Pittsburgh, PA 15213, USA ${ }^{2}$ Acute Lung Injury Center of Excellence, University of Pittsburgh School of Medicine, Pittsburgh, PA 15213, USA

Full list of author information is available at the end of the article
}

Although ARDS results from a wide variety of disorders, sepsis is its main cause and the risk factor most associated with high mortality [4-6]. Regardless of the cause, the alveolar epithelium and capillary endothelium are affected, leading to an increase in permeability allowing protein-rich fluid to accumulate in the alveolar space [7-9]. The loss of epithelial integrity disrupts alveolar clearance and production of surfactant [10-12]. In addition to the alveolar damage, there is an influx of circulating inflammatory cells and formation of hyaline membranes usually caused by the mechanical ventilation. If the inflammatory process is severe enough, there will be ensuing disorganized repair resulting in fibrosis [13].

Existing therapy is currently limited to supportive care $[14,15]$. A novel potential therapy for ARDS is the use of bone marrow-derived mesenchymal stem cells (B-MSC)

\section{Ciomed Central}

(c) 2014 Rojas et al.; licensee BioMed Central Ltd. This is an Open Access article distributed under the terms of the Creative Commons Attribution License (http://creativecommons.org/licenses/by/2.0), which permits unrestricted use, distribution, and reproduction in any medium, provided the original work is properly credited. The Creative Commons Public Domain Dedication waiver (http://creativecommons.org/publicdomain/zero/1.0/) applies to the data made available in this article unless otherwise stated. 
[16-20]. We have previously demonstrated that the infusion of B-MSC isolated from mice and swine prevented inflammation and aberrant repair of endotoxin-induced lung injury in both species [19,21-23]. These effects, together with the restoration of fluid clearance and the decrease in bacterial growth, have also been shown in an ex-vivo perfused human lung model of septic ARDS [16]. There is strong evidence that in models of ARDS, after infusion B-MSC are activated inducing secretion of multiple soluble factors that results in significantly lower levels of inflammatory cytokines in both plasma and bronchoalveolar lavage (BAL) [19,20,24,25]. B-MSC are also able to alter the systemic redox environment characteristic of ARDS to a less oxidizing value [18,26-30] and restore the alveolar epithelium and endothelium integrity and permeability, decreasing airspace neutrophils $[30,31]$. The transfer of functional mitochondria from BMSC to the epithelium has been proven instrumental in the repair process of the lung [32-34] and B-MSCs have also been shown to have anti-bacterial effects that are very beneficial in the septic environment [35-38].

We designed a preclinical large animal model of endotoxin-induced ARDS in order to evaluate the safety and efficacy of the use of adult bone marrow-derived stem cells, named MultiStem (Athersys, Cleveland, $\mathrm{OH}$ ) in the treatment of moderate-to-severe ARDS. In the present study, sheep with lipopolysaccharide (LPS)-induced ARDS received Good Manufacturing Practice (GMP)MultiStem, which have been used in clinical trials for organs other than the lung $[39,40]$, with no toxicity reported. Our results suggest that MultiStem have the ability to reduce the duration and severity of the injury, without detected secondary toxic effects. This allows us to propose the translation of bone marrow-derived stem cells into clinical studies for the treatment of patients with ARDS.

\section{Methods}

\section{Animal mode}

Fourteen adult Dorsett Cross sheep weighing 36.5 to $65 \mathrm{~kg}$ were used in the present study. All animals received humane care in compliance with the 'Principles of Laboratory Animal Care' formulated by the National Society for Medical Research and the 'Guide for the Care and Use of Laboratory Animals' prepared by the Institute of Laboratory Animal Resources and published by the National Institutes of Health (NIH) (NIH no. 86-23). The Institutional Animal Care and Use Committee (IACUC) for Animal Research of the University of Pittsburgh approved all experimental procedures in advance. The use of human stem cells in animals was approved by the Human Stem Cell Research Oversight (hSCRO) Office at the University of Pittsburgh.

A Swan-Ganz catheter was inserted through the jugular vein, after which open chest superior vena cava and main pulmonary artery were cannulated. The sheep received intravenously via the Swan-Ganz catheter 1 and $3.5 \mu \mathrm{g} / \mathrm{kg}$ E. coli endotoxin LPS from E. coli 055:B5 (Sigma, St. Louis, MO, USA) in normal saline (Baxter, Deerfield, IL, USA) over 30 minutes at $0.7 \mathrm{~mL} /$ minute to induce moderate-to-severe ARDS, as defined by the ARDS Definition Task Force [2]. The experimental group (stem cell) received 4, 10 or 40 million MultiStem cells intrabronchially into the lower left lung 30 minutes after the end of LPS infusion. The control group received the same volume intrabronchially of saline (Figure S1 in Additional file 1).

\section{Adult stem cell isolation and administration}

MultiStem were isolated from a human donor bone marrow aspirate. Bone marrow aspirates were acquired with consent and in accordance with 21 CFR Part 1271 Human Cells, Tissues, and Cellular and Tissue Based Products and approved by the Institutional Review Board. Cell isolation was processed according to previously described methods [41]. Briefly, human MultiStem were isolated from a single bone marrow aspirate, obtained with consent from a healthy donor, and cultured in fibronectincoated plastic tissue culture flasks. Cell cultures were maintained under low oxygen tension in a humidified atmosphere of $5 \% \mathrm{CO}_{2}$. Cells were cultured in MultiStem culture media: low-glucose (D)MEM (Life Technologies, Grand Island, NY, USA) supplemented with FBS (fetal bovine serum; Atlas, Fort Collins, CO, USA), ITS liquid media supplement (Sigma), MCDB \{AU Query: Please spell out what ITS and MCDB stand for followed by (ITS) and (MCBD), respectively.\} (Sigma), platelet-derived growth factor (R\&D Systems, Minneapolis, MN, USA), epidermal growth factor (R\&D Systems), dexamethasone, penicillin/ streptomycin (Life Technologies), 2-phospho-L-ascorbic acid and linoleic acid-albumin (Sigma). Cells were passaged every three to four days and harvested using trypsin/ethylenediaminetetraacetic acid (EDTA) (Life Technologies). The cells were positive for CD49c and CD90 and negative for MHC class II and CD45 (all antibodies (Abs) were from BD Biosciences, San Jose, CA, USA). Cells were cryopreserved in MultiStem media and $10 \%$ dimethyl sulfoxide (DMSO). Before administration cells were counted with trypan blue exclusion and final concentration adjusted according with the percentage of alive cells. Preparations in which cell viability were lower that $90 \%$ were discarded.

\section{Data acquisition and analysis}

In all groups, blood gases and blood sampling were performed in a Radiometer ABL 725 (Radiometer, Westlake, $\mathrm{OH}$, USA) before the endotoxin administration and every 30 minutes for the duration of the study (Figure S1 in Additional file 1). To have a better understanding 
of the lung function, open chest hemodynamic measurements, aortic pressure (AoP), pulmonary artery pressure (PAP), central venous pressure (CVP), and left atrial pressure (LAP) were monitored with catheter-tip manometers (Additional file 1 and Figure S2 in Additional file 1). Cardiac output (CO) was monitored continuously. All hemodynamic parameters were recorded electronically in a secure access hard drive for further analysis.

\section{Histopathologic evaluation}

Lung biopsies of 1 to $2 \mathrm{~cm}^{3}$ were performed at the lower lobes (left and right) before and after endotoxin and at the end of the experiment (Figure 1A). A piece of each biopsy was fixed with $10 \%$ non-buffered formalin for 24 hours, paraffinized and sectioned for subsequent staining with hematoxylin and eosin for histological assessment using light microscopy (Nikon Eclipse 55i, Melville, NY, USA). The rest of the tissue was used for wet-to-dry analysis.

\section{Wet to dry ratio}

Pieces of the biopsies from the lower lobes of the lungs from each of the three time points described were divided into five 2 to $3 \mathrm{~mm}^{2}$ fragments each for use as technical replicates and flash frozen separately for later weighing. The tissues were dried overnight in a Savant DNA120
SpeedVac Concentrator (ThermoFisher, Pittsburgh, PA, USA) and reweighed, then the wet-to-dry ratio (W/D) was determined as the percent change after injury, $\frac{\left(\frac{W}{D}\right) f}{\left(\frac{W}{D}\right) t} 100-100$ (where $W$ is the wet weight, $D$ is the dry weight, $f$ is the final biopsy at the end of the study and $i$ the biopsy one hour after endotoxin).

\section{Statistical analysis}

Comparison between the control group and the groups treated with MultiStem, as well as the comparison between baseline and the following time points within a group were tested with independent student $t$-tests. The differences in the results were considered to be statistically significant when the $P$-value was less than 0.05 .

\section{Results and discussion}

We were able to demonstrate morphological and physiological changes consistent with moderate-to-severe ARDS as a consequence of systemic administration of a single dose of endotoxin. After endotoxin infusion, lung congestion and edema were visually apparent, where accumulation of blood and fluid in the lungs is clearly recognized (Figure 1B-C). The observed changes reached a peak one hour after the end of the infusion of the endotoxin.

\section{A}
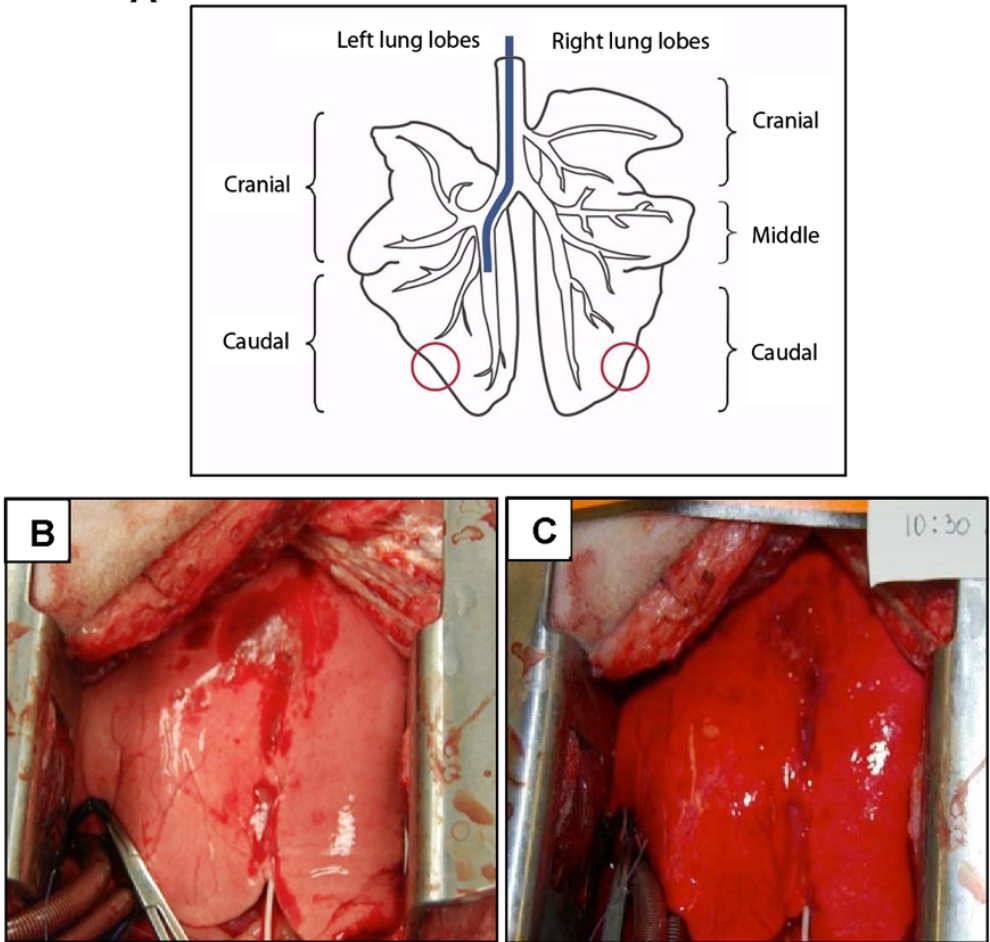

Figure 1 Sheep lung diagram and pictures. (A) The blue line represents the path of the bronchoscope to deliver the adult stem cells or saline The red circumferences show the areas where the lung tissues were sampled. Lung congestion and edema are visually apparent as a consequence of endotoxin infusion. Pictures of the left lung of a sheep before (B) and one hour after the end of the infusion of endotoxin (C). 
In the initial reports by our group, we delivered intravenously B-MSCs to mice and swine with LPS-induced lung injury demonstrating protection with non- or minimal engraftment $[19,25,30]$. In the present work, we decided to deliver a similar cell type intratracheally. The rationale for the change in the route of delivery was based on the possible clinical use of the cells by reducing possible secondary effects. During ARDS, in addition to the deteriorated pulmonary function, there is accumulation of circulatory cells by an increase in the adherence to the endothelium. Furthermore, the large size of the mesenchymal stem cells (close to $100 \mu \mathrm{m}$ in diameter) that circulate in the $10 \mu \mathrm{m}$ microvessels of the lung increases the risk of pulmonary microemboli [42]. In addition, we decided to deliver the cells into only one lung leaving the other lung intact to reduce possible major complications. However, it is important that several studies have demonstrated that during lung injury intravenous and intratracheal administration of mesenchymal stem cells can prompt lung protection $[16,43]$.

\section{Blood gas and hemodynamic data}

Blood oxygenation and $\mathrm{CO}_{2}$ clearance are the primary functions of the lung. One of the main characteristics that defines ARDS is a deficit in these functions, where oxygenation capacity is impaired and the hypoxemia level falls below a $\mathrm{PaO}_{2} / \mathrm{FiO}_{2}$ ratio of $300 \mathrm{mmHg}$ [2]. In this animal model we reproduced the pathophysiology of ARDS observed in humans by administering bacterial endotoxin systemically in sheep. We first evaluated the effect of endotoxin on changes in lung function; as we show in Figure 2A, endotoxin was administered intravenously and blood gas analysis demonstrated an induction of moderate-to-severe ARDS by the $\mathrm{PaO}_{2} / \mathrm{FiO}_{2}$ levels. We evaluated the effect of two different doses of endotoxin, 1 and $3.5 \mu \mathrm{g} / \mathrm{ml}$ intravenously. With both concentrations we observed a rapid decrease in the $\mathrm{PaO}_{2}$, reaching its minimum one hour after the end of endotoxin infusion followed by steady recovery. $\mathrm{PaO}_{2} / \mathrm{FiO}_{2}$ values in both groups dropped $77 \pm 10 \%$ (standard error, SE) from baseline level at its minimum $(102 \pm 10 \mathrm{mmHg})$. We decided to use the higher dose because of the reproducibility between experiments and because after five hours the recovery was only partial.

Similarly, multiple doses of MultiStem were used before selecting the most appropriate. As shown in Figure 2B, doses of 2 and 10 million cells failed to induce significant protection. There was only a marginal effect, when a dose of 10 million was used. In contrast, 40 million cells clearly were able to accelerate the recovery. This group displayed $\mathrm{PaO}_{2} / \mathrm{FiO}_{2}$ values significantly higher than the control group throughout the experiment $(P<0.02)$ and reached baseline levels less than three hours after the endotoxin infusion, whereas the control group only recovered to $80 \%$ of baseline level by the end of the study while the stem cell group's lowest value was significantly higher $(68 \pm 12 \% \mathrm{SE}$ lower than baseline, $158 \pm 19 \mathrm{mmHg} ; P<0.024)$. From this point, the data presented in the experimental group will be limited to the dose of 40 million.

Immediately after the drop in $\mathrm{PaO}_{2} / \mathrm{FiO}_{2}$, the partial pressure of $\mathrm{CO}_{2}\left(\mathrm{PCO}_{2}\right)$ levels increased comparably in both groups. Nevertheless, half an hour after maximum lung injury (minimum $\mathrm{PaO}_{2} / \mathrm{FiO}_{2}$ ), the experimental group reached the $\mathrm{PCO}_{2}$ baseline level, while the control group stayed higher than the baseline throughout the study $(P<$ 0.005 ) (Figure $2 \mathrm{C}$ ). The stem cell treated animals were followed for more than two hours after returning to baseline, suggesting that there was no need for longer monitoring.

After endotoxin infusion, most of the hemodynamic values showed important changes, with the exception of the heart rate which maintained baseline values in both groups (data not shown). Mean arterial pressure decreased significantly $(P<0.025)$ and remained below baseline values throughout the study duration in both groups (Figure 2D). CVP was increased in the control group after endotoxin without significant differences; however, the experimental group treated with stem cells maintained baseline values throughout the study (data not shown). In the control group, PAP stayed significantly higher than baseline $(51 \pm 2 \%)$ after the endotoxin infusion $(P<0.02)$ throughout the study, whereas two hours after endotoxin, the experimental group had recovered to $24 \pm 2 \%$ higher than baseline values (Figure 2E). CO showed a strong decreasing tendency after endotoxin infusion, without reaching the level of significance (data not shown).

In addition, a well-known complication in patients who required assisted ventilation is ventilator-induced lung injury. In our protocol we used protective ventilation, but we cannot discount that some of the injury we observed was induced during ventilation. However, it has been documented that mesenchymal stem cells have the ability to protect the lungs in rats with ventilator induced lung injury [43]. This may suggest a double protective effect of the MultiStem.

\section{Inflammatory data}

ARDS is characterized by the sequestration of neutrophils in the lung, which results in a low neutrophil count in the circulation. As expected, significantly lower than baseline values were recorded in plasma in both groups after the endotoxin infusion $(P<0.0003)$. The stem cell group recovered to baseline levels of neutrophil counts after the infusion of cells while the control group did not recover until the end of the study (Figure 3). This was consistent with lower plasma levels of the pro-inflammatory cytokine IL-8, in which plasma levels after injury were higher in the control group compared to levels in the experimental 


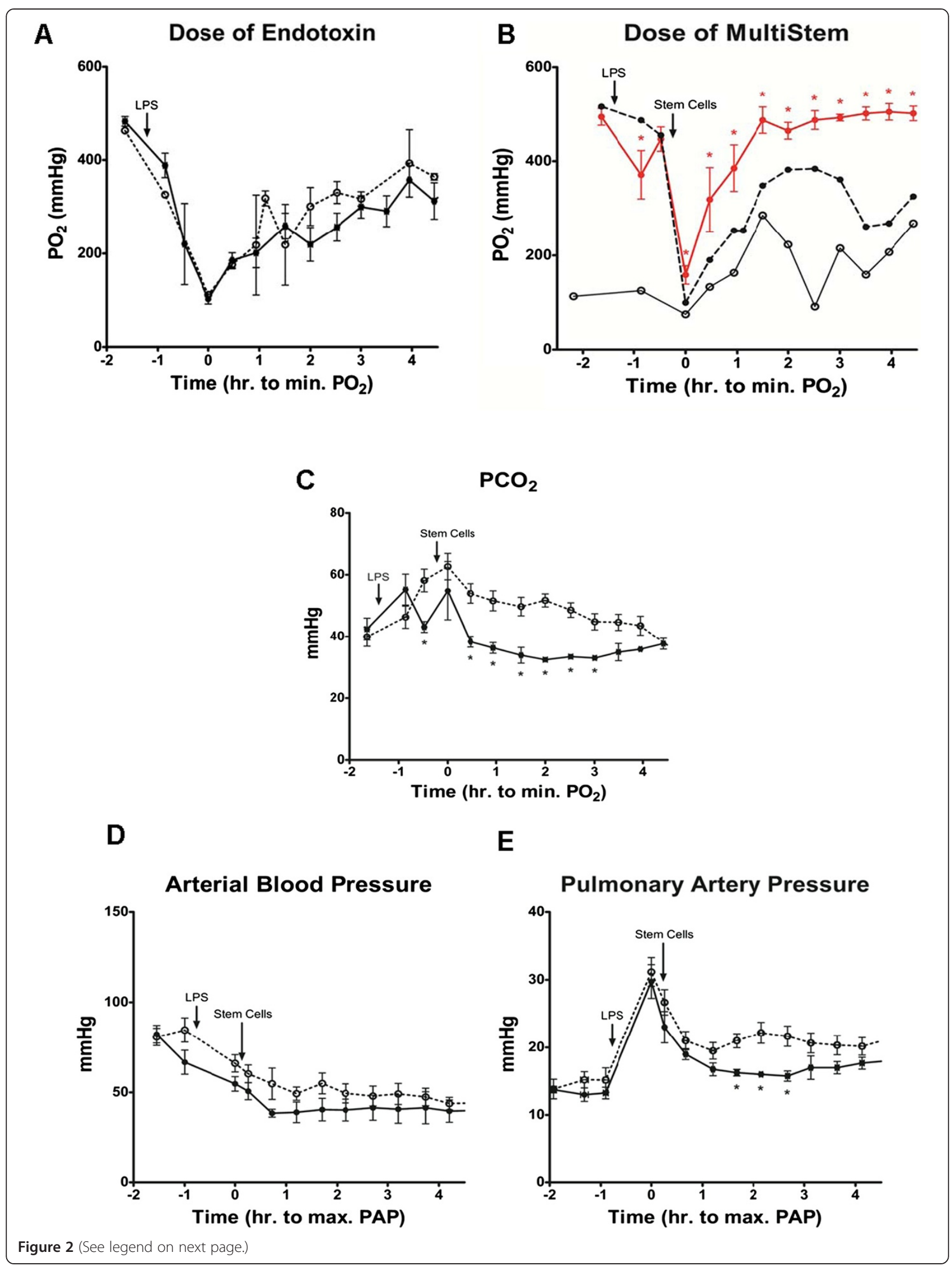


(See figure on previous page.)

Figure 2 Treatment with stem cells facilitate the return to arterial basal levels of blood gases and hemodynamics. (A) The most appropriate dose of endotoxin for the control group (no treatment) was first determined; 1 (solid line) and $3.5 \mu \mathrm{g} / \mathrm{kg}$ (dotted line). (B) Similarly, the dose of MultiStem for the experimental group was determined according to their ability to maintain the $\mathrm{PO}_{2}$ levels after instillation. Doses of 4 (solid line), 10 (dotted line) and 40 million (red line) MultiStem were delivered intrabronchially a half hour after the end of LPS injection. The time of highest pulmonary injury (lowest arterial $\mathrm{PO}_{2}$ ) is expressed as time zero. (C) Measurement of the $\mathrm{PCO}_{2}$ levels similarly demonstrated a protective effect in the experimental group (solid line) compared to the control (dotted line). Arterial (D) and pulmonary artery (E) pressures stabilize earlier in animals treated with stem cells. The control group (no treatment) is represented with a dotted line. Forty million stem cells were instilled intrabronchially in the experimental group (solid black) 30 minutes after the end of LPS injection. The time of highest PAP is expressed as time zero. LPS, lipopolysaccharide; PAP, pulmonary artery pressure; $\mathrm{PCO}_{2}$, partial pressure of $\mathrm{CO}_{2}$.

group (Figure 4). IL-6 cytokine was also measured in plasma, but the values did not reach the detection range (data not shown).

\section{Lung edema}

One of the hallmarks of ARDS is the accumulation of alveolar edema due to impaired alveolar fluid clearance and increased microvascular permeability of the lung endothelium, and it is often used as a prognostic tool for morbidity and mortality $[44,45]$. It has been shown by others and us that lung edema is significantly abrogated in animals treated with MSC or leukocyte-depleted bone marrow $[19,20]$. Here we also show an improvement in lung edema upon administration of adult stem cells.

Lung edema was analyzed by W/D of lower lobe lung biopsies. The control group showed an increase of relative water content after injury in both lungs, reaching

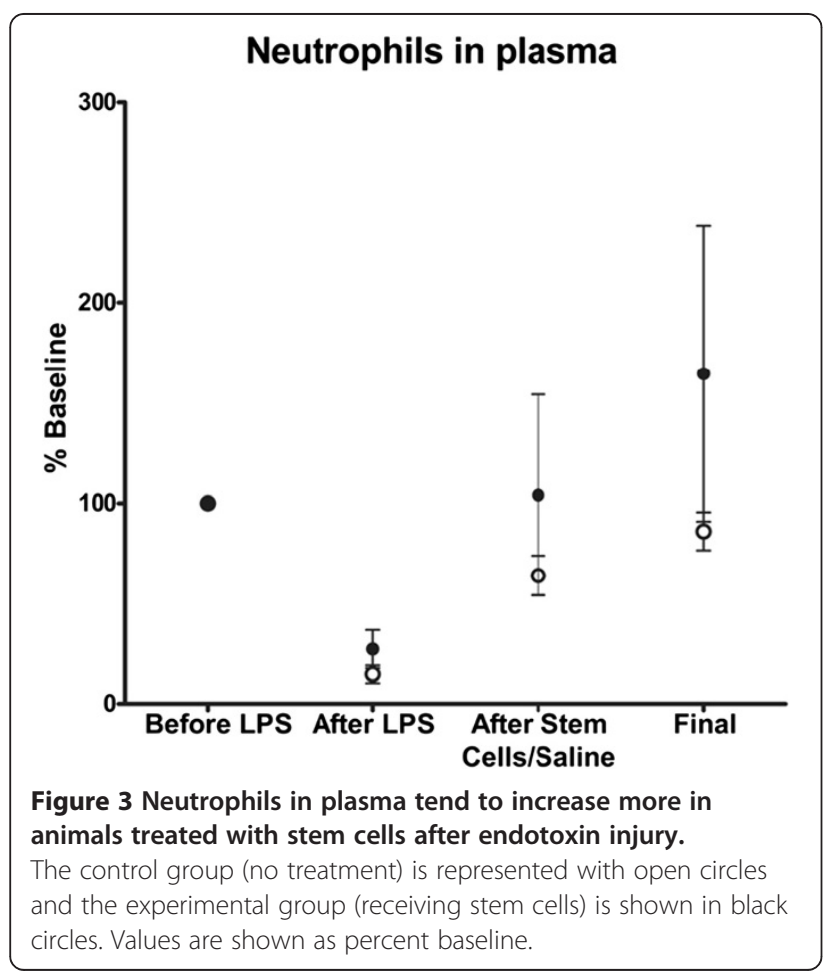

significant differences in the right lung $(P<0.001)$, while treatment with stem cells prevented the increase in edema in either lung (Figure 5A).

\section{Bronchoalveolar lavage Left lung data}

Figure $5(\mathrm{~B}, \mathrm{D})$ shows the series of BAL findings in the left lung (site of cell instillation). Total cell count was observed to be low in both groups after the endotoxin infusion and showed a slight tendency to decrease throughout the study duration. The percentage of neutrophil count had a stable constant trend throughout the study and was detected at lower than baseline values at the end of the study in the control group. The percentage of lymphocytes and monocytes was stable throughout the study (data not shown). None of the changes in the left lung BAL findings reached the level of statistical significance.

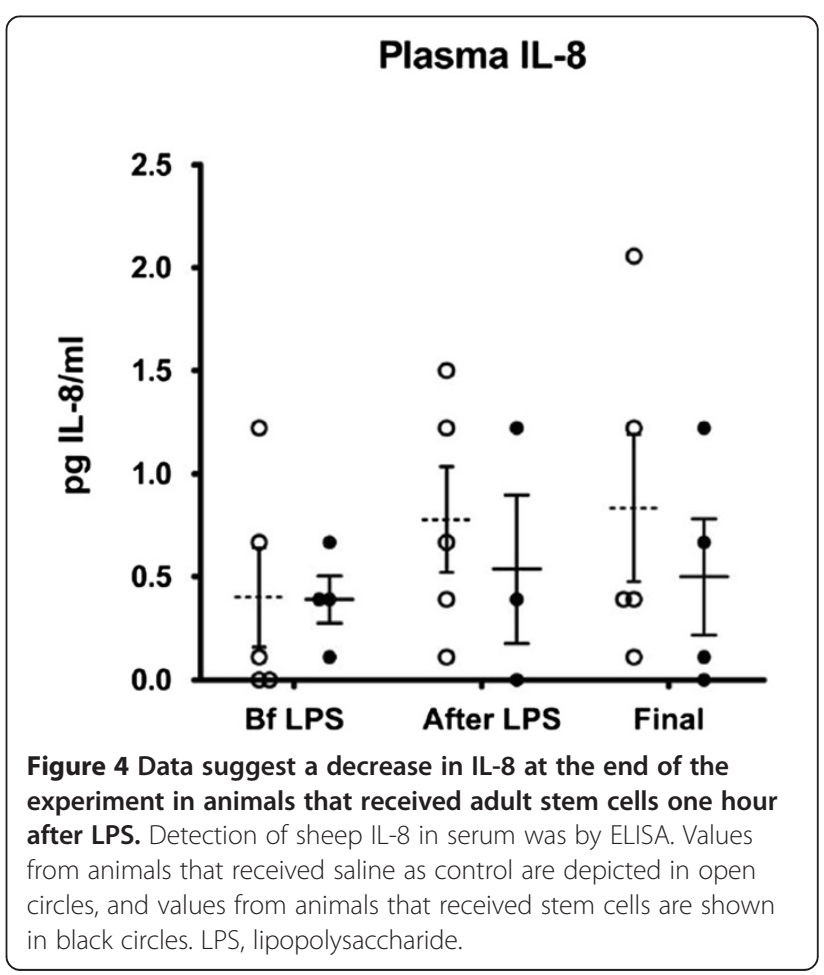




\section{A}

\section{Lung edema}

\section{After treatment}

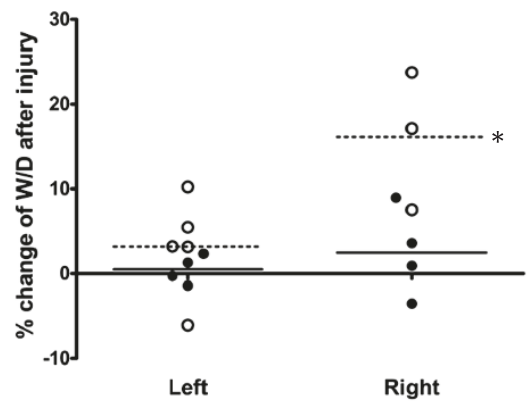

B

Total cell count in Bronchoalveolar lavage Left lung

\section{C}

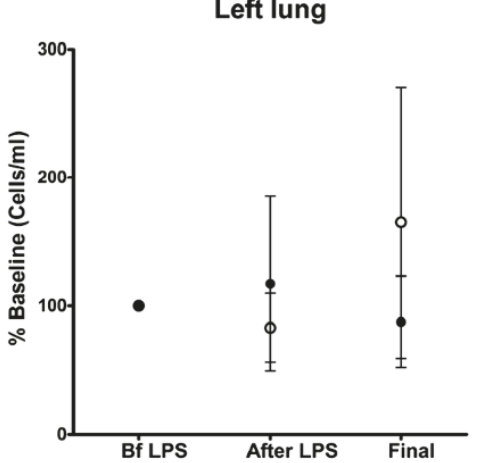

Total cell count in Bronchoalveolar lavage
Right lung

D

\%Neutrophils in Bronchoalveolar lavage Left lung
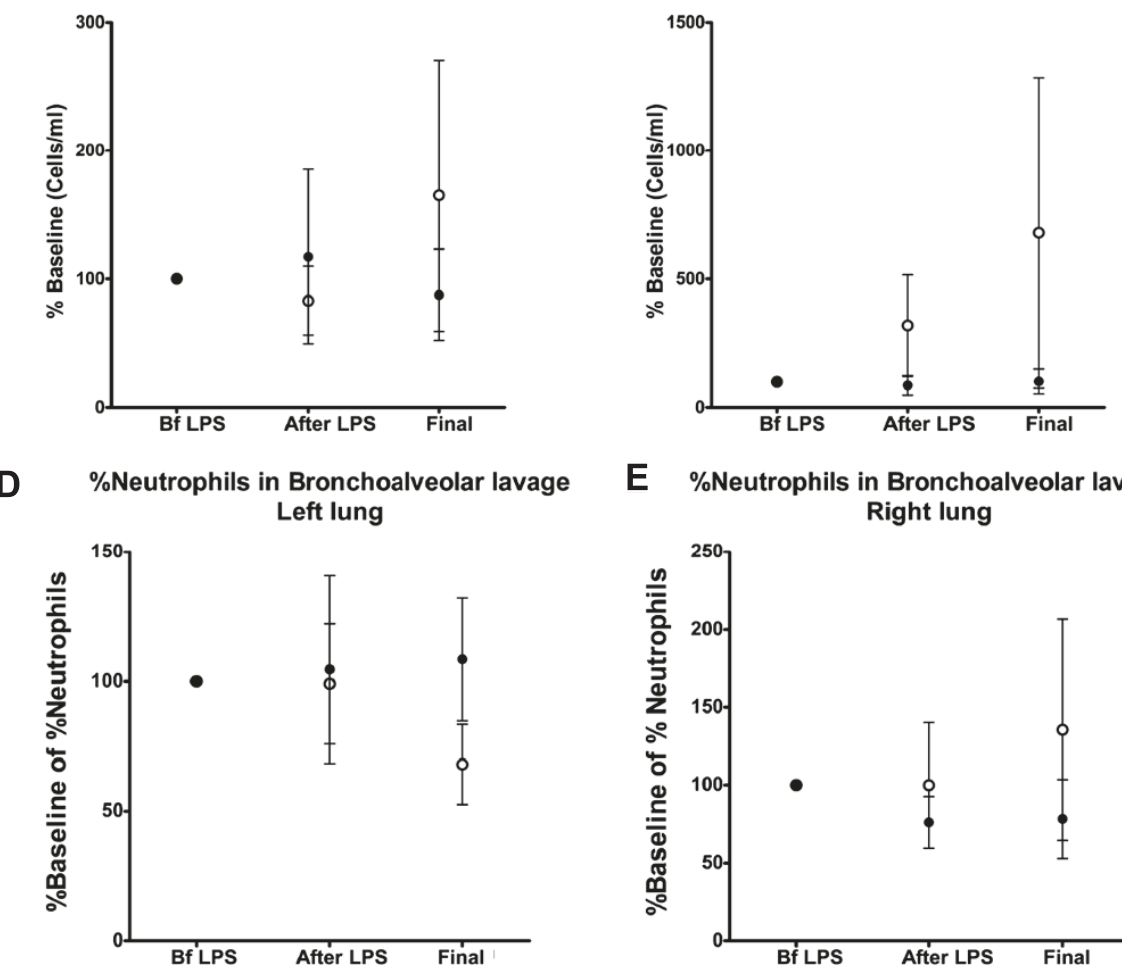

\section{E \%Neutrophils in Bronchoalveolar lavage Right lung}

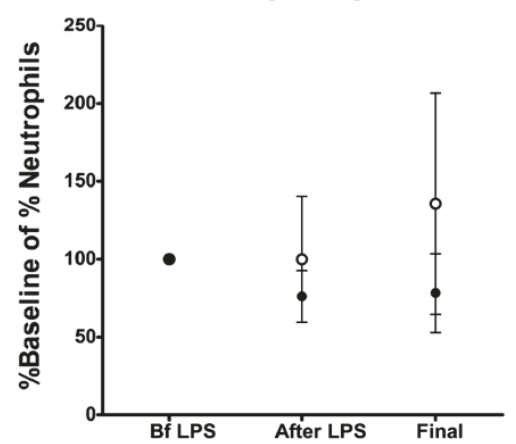

Figure 5 Pulmonary edema is prevented in animals instilled with adult stem cells after endotoxin injury. (A) Tissue samples were collected right before and after endotoxin infusion and at the end of the experiment from both lungs. Water content was measured by calculating the weight before and after the tissue was dehydrated, and the ratio was then calculated. Each sample consisted of five replicates. The control group is represented by open circles and the stem cell group by black circles. Total cell number and neutrophil concentration in bronchoalveolar lavage (BAL) tend to be higher in control animals than in those treated with stem cells. Left (B,D) and right (C,E) lungs. The total cell count in BAL (B, $\mathbf{C})$ and the percent of neutrophils $(\mathbf{D}, \mathbf{E})$ are shown for time points before (Bf) and after endotoxin infusion and at the end of the study. The control group (no treatment) is represented with open circles and the experimental group (receiving stem cells) is shown in black circles.

\section{Right lung data}

Figure $5(\mathrm{C}, \mathrm{E})$ shows the series of BAL findings in the right lung. Total cell count and neutrophil percentage remained stable in both groups. Lymphocytes were stable and monocytes showed a slight tendency to increase after endotoxin and then came back to baseline in the control group. None of the BAL findings in the right lung reached the level of significance.

\section{Histopathologic data}

Left lung

Histopathologic evaluation revealed increased inflammatory cellular infiltration in the control group after the endotoxin infusion. Interstitial acute inflammation with edema, and neutrophil infiltration was evident, while reduced inflammation was recorded before the end of the study in the group treated with stem cells (Figure 6). 


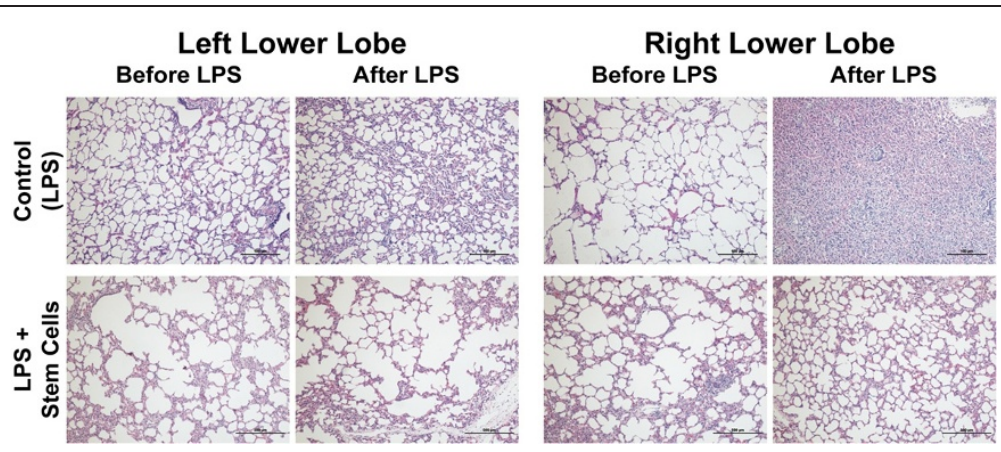

Figure 6 Histological sections of left and right lungs of sheep treated with bacterial endotoxin show less inflammation and congestion in the lungs treated with stem cells. Lung biopsies were fixed in $10 \%$ formalin and stained with hematoxylin and eosin (H\&E; magnification 10x). Sections are shown for left and right lungs before endotoxin infusion and at the end of the study of representative animals of each group (control (LPS) and LPS + stem cells). LPS, lipopolysaccharide.

\section{Right lung}

Histopathologic changes were noted to be severe in the right lung in comparison to the left. As observed in the left lung, reduced inflammation was recorded in the experimental group before the termination of the study (Figure 6).

An interesting observation is the differences in the severity of the injury in the right lung between animals treated or not with MultiStem. The fact that the animals are reposing on their right, under normal conditions during this short period of time fluid accumulation is not detected. However, in the case of LPS-induced ARDS where there are hemodynamic and respiratory failures, fluid cannot be removed which results in severe histological changes and an increase in water counted.

\section{Safety of the intrabronchial delivery of MultiStem in the sheep ARDS model}

As part of this pre-clinical study, several markers of organ function were measured, including in the liver (Figure 7A), pancreas (Figure 7B) and kidney (Figure 7C). Plasma levels of alanine aminotransferase, alkaline phosphatase and aspartate aminotransferase (ASAT) were measured for evaluation of liver function. Plasma levels of amylase, glucose and lipase were quantitated to evaluate pancreatic function, and creatinine and blood urea nitrogen for kidney function. Recorded values fell within the normal ranges expected for sheep. We observed statistical differences in ASAT levels. However, because they were within normal values, these differences do not have biological significance. These results indicate that there was no organ-associated toxicity related to the administration of the MultiStem.

\section{Conclusions}

In order to assess the effectiveness and safety of adult stem cells for the treatment of ARDS, we developed a short-term sheep preclinical model by systemic infusion of endotoxin that resulted in a moderate-to-severe ARDS. The considerable experimental literature demonstrating the protective effects of adult stem cells (for example, B-MSC) in models of ARDS [19,23,46-51], together with the clinical safety experience of MultiStem in previous trials, indicates that these cells will be well-tolerated in the critically ill ARDS population.

The mechanisms by which adult stem cells participate in the repair of the lung following injury have been attributed to their different qualities [16,25,52,53]. The ability of the cells to secrete paracrine factors, such as growth factors and anti-inflammatory cytokines, and to control oxidative damage, protect the endothelium and epithelium, transfer functional mitochondria and secrete antimicrobial peptides has been demonstrated to explain some of the therapeutic effects in the treatment of lung injury in animal in vivo and ex vivo models. Previous studies by our group and others have demonstrated the beneficial effects of the administration of exogenous B-MSC in endotoxemic mice. These studies repeatedly showed a decrease in systemic and local lung inflammation and lung injury $[19,20,23,24]$, demonstrating the anti-inflammatory effect of these cells. Additionally, the immunomodulatory effects and low immunogenicity described for adult stem cells make them promising candidates for therapy. In this study, we show through histologic staining, plasma neutrophil count and plasma pro-inflammatory IL- 8 cytokine levels that there was a marked decrease in inflammation affected by the use of adult stem cells. Is a single dose or multiple doses of MultiStem the most appropriate to treat ARDS? We believe that will, in the future, be a particular decision for each individual patient.

One of the most profound effects of endotoxemia is a decrease in the levels of oxygen in circulation. In our acute preparation, local instillation of stem cells was able 


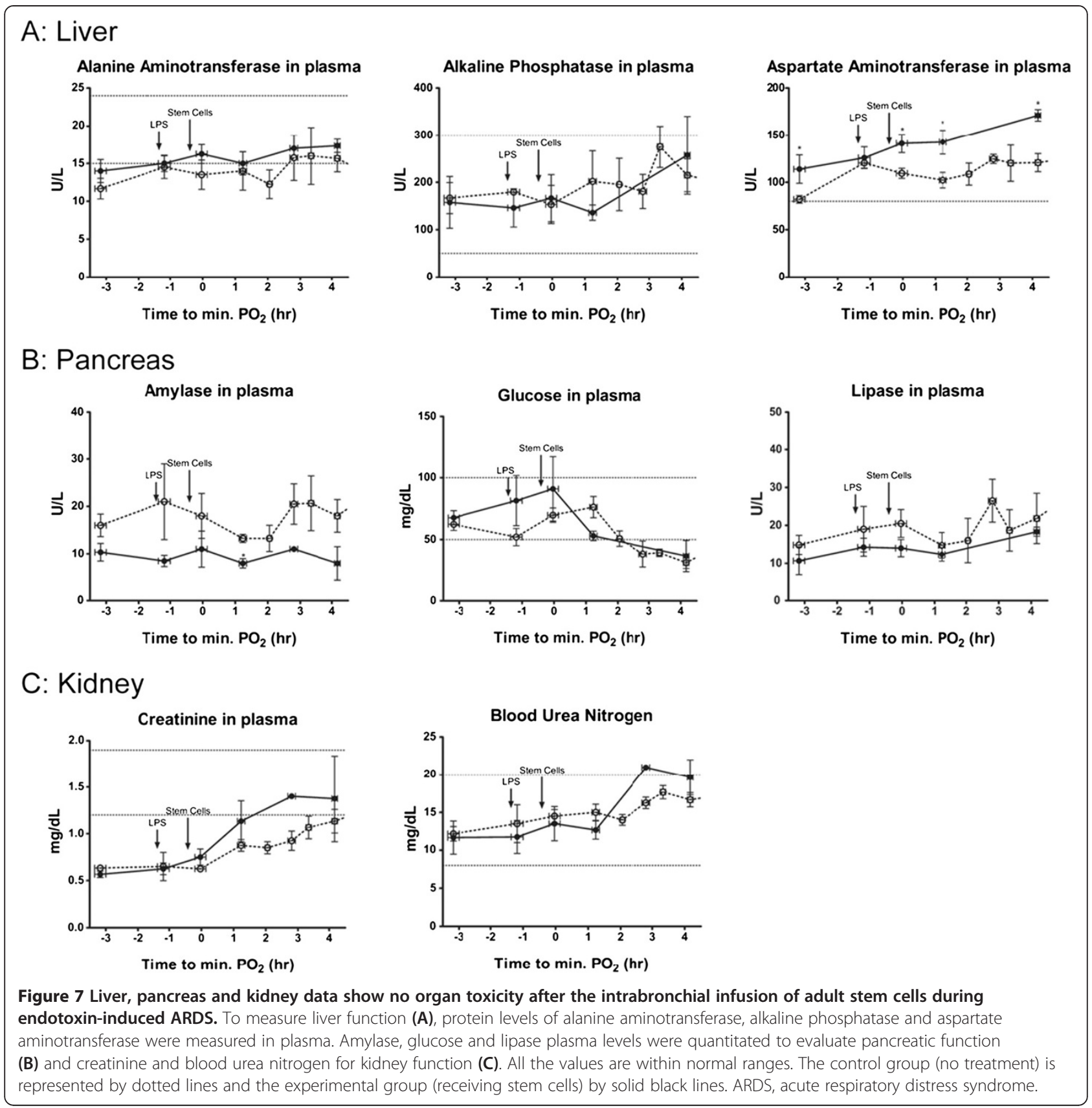

to reduce the severity and decrease the duration of the injury. Although the arterial blood pressure remained low throughout the study in both groups, the infusion of stem cells in ARDS-induced animals attenuated the endotoxemia, as PAP was stabilized to within $20 \%$ of baseline and the control only recovered to $50 \%$.

An important observation was the dramatic distal effect that cells delivered into the left lung had on the right lung. We have two possible explanations. First, because animals are on right lateral recumbency, this favors fluid accumulation. Under normal conditions water accumulation cannot be detected. However, because organ failure during the LPS-induced ARDS and by lost in endothelial barrier there more fluids are produced and this associated with a decrease in normal hemodynamic function results in a 'perfect storm' with a massive accumulation of fluids and inflammatory cells. Second, distal effect can be explained by the secretion of soluble factors by the MultiStem, this paracrine effect has been well documented. Cells injected intravenously accumulate in the lung and have distal effects on the heart and eye $[54,55]$. It is possible that the observed results are the combination of these two mechanisms. 
Furthermore, we monitored organ function of the liver, pancreas and kidney to evaluate the possible toxic effects of the cells. Protein plasma levels fell within normal values for sheep, suggesting no organ-associated toxicity related to the intrabronchial administration of MultiStem during ARDS. Therefore, the use of these cells is considered to be safe in the ARDS model.

Overall, the local administration of adult stem cells to a systemic endotoxemic insult in sheep appears, in the short term, to improve lung function, inflammatory response and hemodynamic changes produced by the bacterial toxin without affecting other organs. Thus, we believe that adult stem cells are a promising candidate for a novel therapy that will help lower the mortality rate in ARDS patients, reducing the associated complications and subsequent multi-organ failure characteristic of this syndrome.

\section{Additional file}

Additional file 1: Figure S1. Experimental model of lung injury in sheep to assess the use of bone marrow derived stem cells. The control and the stem cell groups consisted of six and four sheep, respectively. The ARDS was induced by intravenous infusion of $3.5 \mu \mathrm{g} / \mathrm{kg}$ bacterial endotoxin (LPS). Three bronchoalveolar lavages (BALs) and lung biopsies were performed before endotoxin infusion (baseline), one hour after and at the end of the study. Peripheral blood samples were collected before the infusion and every hour after (time points illustrated with red dots). The experimental group received a dose of 40 million bone marrow-derived stem cells intrabronchially one hour after the start of endotoxin infusion, the control group received a corresponding volume of saline. Figure S2. Diagram of the cannulation in the open chest preparation. The pulmonary artery, left atrium and pulmonary artery are indicated.

\section{Abbreviations}

ARDS: acute respiratory distress syndrome; BAL: bronchoalveolar lavage; B-MSC: bone marrow-derived mesenchymal stem cells; CO: cardiac output; CVP: central venous pressure; $\mathrm{FiO}_{2}$ : fraction of inspired oxygen; IL: interleukin; LPS: lipopolysaccharide; $\mathrm{PaO}_{2}$ : partial pressure of oxygen; PAP: pulmonary artery pressure; W/D: wet to dry ratio.

\section{Competing interests}

$M R, N C, E K, J R T, E C$ and CB declare that they have no competing interests. $\mathrm{RD}$ and AT declare a competing interest; they are employed by Athersys, which provided the cells.

\section{Authors' contributions}

$M R$ and CB were involved in the conception, design, acquisition of data, analysis, interpretation of data and drafting of the manuscript, and agree to be accountable for all aspects of the work in ensuring that questions related to the accuracy or integrity of any part of the work are appropriately investigated and resolved. NC was involved in the acquisition of data, analysis, interpretation of data and drafting of the manuscript, and agrees to be accountable for all aspects of the work in ensuring that questions related to the accuracy or integrity of any part of the work are appropriately investigated and resolved. EK, JRT and EC have made substantial contributions in the acquisition and interpretation of the data and agree to be accountable for all aspects of the work. EK, JRT, EC, RD and AT have been involved in the conception and design of the study and in drafting of the manuscript and revising it critically for important intellectual content. All authors have read and approved the final manuscript.

\section{Acknowledgements}

All the personnel at the large-animal facility at the McGowan Institute for Regenerative Medicine, to Kristin Valchar for her administrative support, Militza R. Romagnoli and Diana Alvarez-Villa for their technical support, Bryan J. McVerry for critical comments and Melanie E. Levine for editing and figure design and to Kenneth L. Brigham, Richard E. Parker and Luis A. Ortiz for participation in the study design.

Support by the Department of Defense Research Grant W81XWH-07-10415, Pittsburgh Tissue Engineering Initiative (PTEI) and University of Pittsburgh, McGowan Institute for Regenerative Medicine.

\section{Author details}

${ }^{1}$ Dorothy P. and Richard P. Simmons Center for Interstitial Lung Diseases, University of Pittsburgh School of Medicine, Pittsburgh, PA 15213, USA. ${ }^{2}$ Acute Lung Injury Center of Excellence, University of Pittsburgh School of Medicine, Pittsburgh, PA 15213, USA. ${ }^{3}$ Division of Pulmonary, Allergy and Critical Care Medicine, University of Pittsburgh School of Medicine, Pittsburgh, PA 15213, USA. ${ }^{4}$ McGowan Institute for Regenerative Medicine, University of Pittsburgh School of Medicine, Pittsburgh, PA 15213, USA.

${ }^{5}$ Division of Cardiothoracic Transplantation, University of Pittsburgh School of Medicine, 3459 Fifth Avenue, Pittsburgh, PA 15213, USA. ${ }^{6}$ Athersys, Inc., 3201 Carnegie Ave., Cleveland, $\mathrm{OH} 44115$, USA.

Received: 8 January 2014 Revised: 17 February 2014 Accepted: 21 March 2014 Published: 26 March 2014

\section{References}

1. Schraufnagel DE: Breathing in America: Diseases, Progress, and Hope. New York: American Thoracic Society; 2010.

2. Ranieri VM, Rubenfeld GD, Thompson BT, Ferguson ND, Caldwell E, Fan E, Camporota L, Slutsky AS: Acute respiratory distress syndrome: the Berlin Definition. JAMA 2012, 307:2526-2533.

3. Ferguson $N$, Fan $E$, Camporota $L$, Antonelli M, Anzueto A, Beale R, Brochard L, Brower R, Esteban A, Gattinoni L, Rhodes A, Slutsky AS, Vincent JL, Rubenfeld GD, Thompson BT, Ranieri VM: The Berlin definition of ARDS: an expanded rationale, justification, and supplementary material. Intensive Care Med 2012, 38:1573-1582.

4. Li S, Wang X, Yan J: High-frequency oscillatory ventilation for cardiac surgery children with severe acute respiratory distress syndrome. Pediatr Cardio/ 2013, 34:1382-1388

5. Tzovaras N, Karvouniaris M, Makris D, Zakynthinos E: Adjunctive therapies in severe pneumonia in critical care patients. Infect Disord Drug Targets 2011, 11:395-400.

6. Bhadade RR, de Souza RA, Harde MJ, Khot A: Clinical characteristics and outcomes of patients with acute lung injury and ARDS. J Postgrad Med 2011, 57:286-290

7. Neamu RF, Martin GS: Fluid management in acute respiratory distress syndrome. Curr Opin Crit Care 2013, 19:24-30.

8. Cortes I, Penuelas O, Esteban A: Acute respiratory distress syndrome: evaluation and management. Minerva Anestesiol 2012, 78:343-357.

9. Bhargava M, Wendt CH: Biomarkers in acute lung injury. Transl Res 2012, 159:205-217.

10. Berger G, Guetta J, Klorin G, Badarneh R, Braun E, Brod V, Saleh NA, Katz A, Bitterman H, Azzam ZS: Sepsis impairs alveolar epithelial function by downregulating Na-K-ATPase pump. Am J Physiol Lung Cell Mol Physiol 2011, 301:L23-L30

11. Piantadosi CA, Schwartz DA: The acute respiratory distress syndrome. Ann Intern Med 2004, 141:460-470.

12. Vadasz I, Weiss $\mathrm{CH}$, Sznajder I: Ubiquitination and proteolysis in acute lung injury. Chest 2012, 141:763-771.

13. Erickson SE, Martin GS, Davis JL, Matthay MA, Eisner MD: Recent trends in acute lung injury mortality: 1996-2005. Crit Care Med 2009, 37:1574-1579.

14. Meade MO, Cook DJ, Guyatt GH, Slutsky AS, Arabi YM, Cooper DJ, Davies AR, Hand LE, Zhou Q, Thabane L, Austin P, Lapinsky S, Baxter A, Russell J, Skrobik Y, Ronco JJ, Stewart TE, Lung Open Ventilation Study Investigators: Ventilation strategy using low tidal volumes, recruitment maneuvers, and high positive end-expiratory pressure for acute lung injury and acute respiratory distress syndrome: a randomized controlled trial. JAMA 2008, 299:637-645.

15. Mercat A, Richard JC, Vielle B, Jaber S, Osman D, Diehl JL, Lefrant JY, Prat G, Richecoeur J, Nieszkowska A, Gervais C, Baudot J, Bouadma L, Brochard L, 
Expiratory Pressure (Express) Study Group: Positive end-expiratory pressure setting in adults with acute lung injury and acute respiratory distress syndrome: a randomized controlled trial. JAMA 2008, 299:646-655.

16. Lee JW, Krasnodembskaya A, McKenna DH, Song Y, Abbott J, Matthay MA: Therapeutic effects of human mesenchymal stem cells in ex vivo human lungs injured with live bacteria. Am J Respir Crit Care Med 2013, 187:751-760.

17. Lee JW, Fang X, Gupta N, Serikov V, Matthay MA: Allogeneic human mesenchymal stem cells for treatment of E. coli endotoxin-induced acute lung injury in the ex vivo perfused human lung. Proc Natl Acad SCi U S A 2009, 106:16357-16362.

18. Iyer SS, Co C, Rojas M: Mesenchymal stem cells and inflammatory lung diseases. Panminerva Med 2009, 51:5-16.

19. Xu J, Woods CR, Mora AL, Joodi R, Brigham KL, Iyer S, Rojas M: Prevention of endotoxin-induced systemic response by bone marrow-derived mesenchymal stem cells in mice. Am J Physiol Lung Cell Mol Physiol 2007, 293:L131-L141.

20. Gupta N, Su X, Popov B, Lee JW, Serikov V, Matthay MA: Intrapulmonary delivery of bone marrow-derived mesenchymal stem cells improves survival and attenuates endotoxin-induced acute lung injury in mice. J Immunol 2007, 179:1855-1863.

21. Xu J, Qu J, Cao L, Sai Y, Chen C, He L, Yu L: Mesenchymal stem cell-based angiopoietin-1 gene therapy for acute lung injury induced by lipopolysaccharide in mice. J Pathol 2008, 214:472-481.

22. Xu YL, Liu YL, Wang Q, Li G, Lu XD, Kong B: Intravenous transplantation of mesenchymal stem cells attenuates oleic acid induced acute lung injury in rats. Chin Med J (Engl) 2012, 125:2012-2018.

23. Rojas M, Parker RE, Thorn N, Corredor C, lyer SS, Bueno M, Mroz L, Cardenes N, Mora AL, Stecenko AA, Brigham KL: Infusion of freshly isolated autologous bone marrow derived mononuclear cells prevents endotoxin-induced lung injury in an ex-vivo perfused swine model. Stem Cell Res Ther 2013, 4:26.

24. Rojas M, XU J, Woods CR, Mora AL, Spears W, Roman J, Brigham KL: Bone marrow-derived mesenchymal stem cells in repair of the injured lung. Am J Respir Cell Mol Biol 2005, 33:145-152.

25. Bustos ML, Huleihel L, Meyer EM, Donnenberg AD, Donnenberg VS, Sciurba $J D$, Mroz L, McVerry BJ, Ellis BM, Kaminski N, Rojas M: Activation of human mesenchymal stem cells impacts their therapeutic abilities in lung injury by increasing interleukin (IL)-10 and IL-1RN levels. Stem Cells Trans/ Med 2013, 2:884-895

26. Penuelas O, Melo E, Sanchez C, Sanchez I, Quinn K, Ferruelo A, Perez-Vizcaino F, Esteban A, Navajas D, Nin N, Peñuelas O, Melo E, Sánchez C, Sánchez I, Quinn K, Ferruelo A, Pérez-Vizcaíno F, Esteban A, Navajas D, Nin N, Lorente JA, Farré R: Antioxidant effect of human adult adipose-derived stromal stem cells in alveolar epithelial cells undergoing stretch. Respir Physiol Neurobiol 2013, 188:1-8.

27. Iyer SS, Torres-Gonzalez E, Neujahr DC, Kwon M, Brigham KL, Jones DP, Mora AL, Rojas M: Effect of bone marrow-derived mesenchymal stem cells on endotoxin-induced oxidation of plasma cysteine and glutathione in mice. Stem Cells Int 2010, 2010:868076.

28. Iyer SS, Ramirez AM, Ritzenthaler JD, Torres-Gonzalez E, Roser-Page S, Mora AL, Brigham KL, Jones DP, Roman J, Rojas M: Oxidation of extracellular cysteine/cystine redox state in bleomycin-induced lung fibrosis. Am J Physiol Lung Cell Mol Physiol 2009, 296:L37-L45.

29. Iyer SS, Jones DP, Brigham KL, Rojas M: Oxidation of plasma cysteine/ cystine redox state in endotoxin-induced lung injury. Am J Respir Cell Mol Biol 2009, 40:90-98.

30. Iyer SS, Accardi CJ, Ziegler TR, Blanco RA, Ritzenthaler JD, Rojas M, Roman J, Jones DP: Cysteine redox potential determines pro-inflammatory IL-1 beta levels. PLoS One 2009, 4:e5017.

31. Takahata Y, Takarada T, lemata M, Yamamoto T, Nakamura Y, Kodama A, Yoneda Y: Functional expression of beta2 adrenergic receptors responsible for protection against oxidative stress through promotion of glutathione synthesis after Nrf2 upregulation in undifferentiated mesenchymal C3H10T1/2 stem cells. J Cell Physiol 2009, 218:268-275.

32. Spees JL, Olson SD, Whitney MJ, Prockop DJ: Mitochondrial transfer between cells can rescue aerobic respiration. Proc Natl Acad Sci U S A 2006, 103:1283-1288.

33. Vallabhaneni $\mathrm{KC}$, Haller $\mathrm{H}$, Dumler I: Vascular smooth muscle cells initiate proliferation of mesenchymal stem cells by mitochondrial transfer via tunneling nanotubes. Stem Cells Dev 2012, 21:3104-3113.
34. Islam MN, Das SR, Emin MT, Wei M, Sun L, Westphalen K, Rowlands DJ, Quadri SK, Bhattacharya S, Bhattacharya J: Mitochondrial transfer from bone-marrow-derived stromal cells to pulmonary alveoli protects against acute lung injury. Nat Med 2012, 18:759-765.

35. Krasnodembskaya A, Samarani G, Song Y, Zhuo H, Su X, Lee JW, Gupta N, Petrini M, Matthay MA: Human mesenchymal stem cells reduce mortality and bacteremia in gram-negative sepsis in mice in part by enhancing the phagocytic activity of blood monocytes. Am J Physiol Lung Cell Mol Physiol 2012, 302:L1003-L1013.

36. Krasnodembskaya A, Song Y, Fang X, Gupta N, Serikov V, Lee JW, Matthay MA: Antibacterial effect of human mesenchymal stem cells is mediated in part from secretion of the antimicrobial peptide LL-37. Stem Cells 2010, 28:2229-2238

37. Nijnik A, Hancock RE: The roles of cathelicidin LL-37 in immune defences and novel clinical applications. Curr Opin Hematol 2009, 16:41-47.

38. Meisel R, Brockers S, Heseler K, Degistirici O, Bülle H, Woite C, Stuhlsatz S, Schwippert W, Jäger M, Sorg R, Henschler R, Seissler J, Dilloo D, Däubener W: Human but not murine multipotent mesenchymal stromal cells exhibit broad-spectrum antimicrobial effector function mediated by indoleamine 2,3-dioxygenase. Leukemia 2011, 25:648-654.

39. Penn MS, Ellis S, Gandhi S, Greenbaum A, Hodes Z, Mendelsohn FO, Strasser $D$, Ting $A E$, Sherman $W$ : Adventitial delivery of an allogeneic bone marrow-derived adherent stem cell in acute myocardial infarction: phase I clinical study. Circ Res 2012, 110:304-311.

40. Vaes B, Van't Hof W, Deans R, Pinxteren J: Application of MultiStem((R)) allogeneic Cclls for immunomodulatory therapy: clinical progress and pre-clinical challenges in P prophylaxis for graft versus host disease. Front Immunol 2012, 3:345.

41. Boozer S, Lehman N, Lakshmipathy U, Love B, Raber A, Maitra A, Deans R, Rao MS, Ting AE: Global characterization and genomic stability of human MultiStem, a multipotent adult progenitor cell. J Stem Cells 2009, 4:17-28.

42. Furlani D, Ugurlucan M, Ong L, Bieback K, Pittermann E, Westien I, Wang W, Yerebakan C, Li W, Gaebel R, Li RK, Vollmar B, Steinhoff G, Ma N: Is the intravascular administration of mesenchymal stem cells safe? Mesenchymal stem cells and intravital microscopy. Microvasc Res 2009, 77:370-376.

43. Chimenti L, Luque T, Bonsignore MR, Ramirez J, Navajas D, Farre R: Pre-treatment with mesenchymal stem cells reduces ventilator-induced lung injury. Eur Respir J Supp/ 2012, 40:939-948.

44. Matthay MA, Wiener-Kronish JP: Intact epithelial barrier function is critical for the resolution of alveolar edema in humans. Am Rev Respir Dis 1990, 142:1250-1257.

45. Ware LB, Matthay MA: Alveolar fluid clearance is impaired in the majority of patients with acute lung injury and the acute respiratory distress syndrome. Am J Respir Crit Care Med 2001, 163:1376-1383.

46. Pati S, Gerber MH, Menge TD, Wataha KA, Zhao Y, Baumgartner JA, Zhao J, Letourneau PA, Huby MP, Baer LA, Salsbury JR, Kozar RA, Wade CE, Walker PA, Dash PK, Cox CS Jr, Doursout MF, Holcomb JB: Bone marrow derived mesenchymal stem cells inhibit inflammation and preserve vascular endothelial integrity in the lungs after hemorrhagic shock. PLoS One 2011, 6:e25171.

47. Cancio LC: Airway management and smoke inhalation injury in the burn patient. Clin Plast Surg 2009, 36:555-567.

48. Matthay MA, Thompson BT, Read EJ, McKenna DH Jr, Liu KD, Calfee CS, Lee JW: Therapeutic potential of mesenchymal stem cells for severe acute lung injury. Chest 2010, 138:965-972.

49. Matthay MA, Goolaerts A, Howard JP, Lee JW: Mesenchymal stem cells for acute lung injury: preclinical evidence. Crit Care Med 2010, 38:S569-S573.

50. Fang X, Neyrinck AP, Matthay MA, Lee JW: Allogeneic human mesenchymal stem cells restore epithelial protein permeability in cultured human alveolar type II cells by secretion of angiopoietin-1. J Biol Chem 2010, 285:26211-26222.

51. Iyer SS, Rojas M: Anti-inflammatory effects of mesenchymal stem cells: novel concept for future therapies. Expert Opin Biol Ther 2008, 8:569-581.

52. Yilmaz S, Inandiklioglu N, Yildizdas D, Subasi C, Acikalin A, Kuyucu Y, Bayram I, Topak A, Tanyeli A, Duruksu G, Karaoz E: Mesenchymal stem cell: does it work in an experimental model with acute respiratory distress syndrome? Stem Cell Rev 2013, 9:80-92.

53. Cardenes N, Caceres E, Romagnoli M, Rojas M: Mesenchymal stem cells: a promising therapy for the acute respiratory distress syndrome. Respiration 2013, 85:267-278. 
54. Oh JY, Lee RH, Yu JM, Ko JH, Lee HJ, Ko AY, Roddy GW, Prockop DJ: Intravenous mesenchymal stem cells prevented rejection of allogeneic corneal transplants by aborting the early inflammatory response. Mol Ther 2012, 20:2143-2152.

55. Danchuk S, Ylostalo JH, Hossain F, Sorge R, Ramsey A, Bonvillain RW, Lasky JA, Bunnell BA, Welsh DA, Prockop DJ, Sullivan DE: Human multipotent stromal cells attenuate lipopolysaccharide-induced acute lung injury in mice via secretion of tumor necrosis factor-alpha-induced protein 6. Stem Cell Res Ther 2011, 2:27.

doi: $10.1186 /$ scrt430

Cite this article as: Rojas et al: Human adult bone marrow-derived stem cells decrease severity of lipopolysaccharide-induced acute respiratory distress syndrome in sheep. Stem Cell Research \& Therapy 2014 5:42.

\section{Submit your next manuscript to BioMed Central and take full advantage of:}

- Convenient online submission

- Thorough peer review

- No space constraints or color figure charges

- Immediate publication on acceptance

- Inclusion in PubMed, CAS, Scopus and Google Scholar

- Research which is freely available for redistribution 